\title{
Detection of Toxocara cati from Fecal Samples of Domestic Pet Cats at Pet Clinic Surabaya and Durability of Toxocara cati Eggs with In Vitro Media
}

\author{
O. R. P. A. Nussa, A. Kurnianto, and I. P. Hermawan \\ Fakultas Kedokteran Hewan, Universitas Wijaya Kusuma Surabaya, \\ Jl. Dukuh Kupang XXV No.54 Surabaya \\ Corresponding author: intanpermatasari@uwks.ac.id
}

\begin{abstract}
The purpose of this study was to determine the presence of Toxocara cati eggs in the feces of Domestic pet cats at the Surabaya Animal Clinic and the durability of Toxocara cati eggs with in vitro media. Total fecal samples taken were 30 cat feces from 5 animal clinics in Surabaya, then detected Toxocara cati eggs using an enlargement microscope 100 times, followed by counting eggs per gram of feces. The eggs used were approximately 200 eggs in each petri dish, then positive feces of Toxocara cati with various in vitro media using $0.9 \% \mathrm{NaCl}, 1 \% \mathrm{PBS}$ and $1 \% \mathrm{CMC}$ for 24 hours and 48 hours. The results showed that two fecal samples positive Toxocara cati from 30 samples fecal and durability Toxocara cati eggs on medium in vitro over 24 showed 28\% NaCl; PBS 68\%; CMC 5\% and at 48 hours showed 23.7\% NaCl; PBS 58\%; CMC 17.3\%. Based on these results, the conclusion is two fecal $(6,67 \%)$ positive T.cati from 30 fecal samples, and the best medium in the test of the durability of Toxocara cati egg is $1 \%$ PBS.
\end{abstract}

Keywords: Toxocara cati, domestic pet cats, medium in vitro, PBS

\section{INTRODUCTION}

Toxocariasis is a parasitic disease of the cat's intestines caused by Toxocara cati. This worm belongs to the Ascaridae family, the genus Toxocara. Most of the life of the Toxocara worm is inside the cat's body. The eggs produced by adult worms are excreted in the feces and last 10 to 14 days. Worm eggs can survive in dry environments. Worm eggs can be damaged when exposed to hypochlorite (bleach) solution for 10 minutes. These worms will multiply in the intestines and cause intestinal disorders (Nealma et al., 2013).

Domestic pet cats are domestic cats kept and lived with the house owner. Domestic pet cats are divided into three caring systems: indoor, limited, and free-range. Cats that are not allowed to leave the house and tame are an indoor category. The limited range category is cats that are allowed to leave the house but are only limited to neighbours and are still under the supervision of their owners. While free-range is a category of cats allowed to leave the house without supervision, these cats are usually less docile (Hildreth et al., 2010).

Toxocariasis infection does not only occur in cats but is also zoonotic (capable of infecting humans) (Cunningham et al., 1992). Toxocariasis infection is one of the most common parasites found in humans. An infection can cause the incidence of Toxocariasis in humans in pets (Cunningham et al., 1992).

Toxocariasis infection in humans is often found because cats are favourite pets. Due to direct contact of infected cats with humans, transmission to humans is possible. Clinical symptoms of humans infected with Toxocara are vomiting, and ocular larvae migrants, namely, the larvae migrate to the eyes so that eye damage can occur (Morsy, 2020).

Research conducted by Roeswandono et al. (2019) showed that the degree of Toxocariasis in stray cats in Dukuh Kupang Surabaya was moderate, and the white blood cell examination showed typical eosinophil values and an increase in lymphocytes with an average of 10.72 x103 $/ \mu \mathrm{L}$. Toxocariasis cases were recorded in $10 \mathrm{dogs}$ in the Padang Bulan village in 2012 (Manurung, 2012).

The prevalence of Toxocara cati infection in cats in northern Iran was $24.2 \%$ in a meta-analysis (Eslahi et al., 2020). Research conducted by Ursche et al. (2021) that cases of Toxocara cati found in the intestinal tract was $40.2 \%$ of the 137 fecal samples examined at the Faculty of Veterinary Medicine, University of Agriculture and Veterinary Medicine, ClujNapoca. In Indonesia, the prevalence of $T$. cati infection in Denpasar is $48.8 \%$ (Nealma et al., 2013), while in Surabaya the prevalence of $T$. cati by examination through gastrointestinal surgery is $60.9 \%$ (Kusnoto, 2005). 
Diagnosis by examination of feces is a method that is often done because it is easy and fast; it can also be followed by an examination of anatomical and clinical pathology (Sudardjat, 2012). In vitro egg storage media is carried out on artificial media to grow and reproduce at optimal temperatures or environments (Ikrom et al., 2014). From this background, it is necessary to detect Toxocara cati eggs and test the durability of Toxocara cati eggs with various in vitro media.

\section{MATERIAL AND METHODS}

\section{Research Tools and Materials}

The tools used in this research are a cool box, beaker glass, tube pot, toothpick, dropper, object-glass, cover glass, gauze or filter, centrifugation tube, petri dish, and microscope.

The materials used in this study were fresh feces from cats at the veterinary clinic, distilled water and formalin buffer $10 \%$, Sodium Chloride $(\mathrm{NaCl})$ 0.9\%, Phosphate Buffer Saline (PBS) 1\%, Carboxy Methyl Cellulose (CMC) $1 \%$.

\section{Stool Sampling}

Samples of cat feces suspected of being infected with worms were obtained from veterinary clinics in the Surabaya area. Samples were taken in fresh feces from cats suspected of being infected with worms. The total samples taken were 30 samples of cat feces.

Stool samples were taken using a sterile cotton swab. The feces were accommodated in a container in a sterile sample pot filled with $10 \%$ formalin and then the feces were stored in a cool box. The sample pots are labelled with date of sampling, the sex of cat, the type or breed of cat, and the name of the veterinary clinic intended.

\section{Stool Examination}

Three grams were dissolved with $17 \mathrm{ml}$ of water for a few minutes; after being soft and then crushed, $40 \mathrm{ml}$ of saturated salt solution were added to float the eggs. Then the fecal solution is stirred and taken with a pipette and put in the Whitlock counting chamber.

The Toxocara cati eggs found were then counted (in the McMaster counting chamber) using a microscope with a magnification of 40 times so that the number was multiplied by 40 . The quantitative examination aimed to determine how many worm eggs are in each gram of feces or eggs per gram (TPG) of feces which describes the lightweight. The degree of parasitic infection (Ekawasti et al., 2017).

\section{In vitro media}

In vitro test is a technique outside the body of living things using a petri dish or test tube. In vitro media is used for tests as object storage within a specific time. The media used in the in vitro test were $0.9 \% \mathrm{NaCl}, 1 \% \mathrm{PBS}$, and $1 \% \mathrm{CMC}$.

\section{Toxocara cati Egg Durability Test}

The test was conducted to determine the resistance of Toxocara cati eggs to storage media at room temperature in vitro using a petri dish. This study used three (3) media were $0.9 \% \mathrm{NaCl}$, $1 \% \mathrm{PBS}$, and $1 \% \mathrm{CMC}$.

This test was carried out with three repetitions of each medium, each medium filled with 200 eggs. Observation time was 24 hours and 48 hours to see which medium was the best for storing Toxocara cati worm eggs.

\section{Data analysis}

The research data were tabulated using the Microsoft Excel program and analyzed descriptively, both qualitative data and quantitative data.

\section{RESULTS AND DISCUSSION}

The detection of worm eggs from 30 samples of domestic cat feces at the Surabaya clinic found two positive Toxocara cati eggs, or about $6.67 \%$ of the 30 total samples. Based on microscopic examination with 100 times magnification and based on morphology, Toxocara cati eggs have the characteristics of oval, jagged, and thick-walled eggs (Koesdarto $e t$ al., 2000).

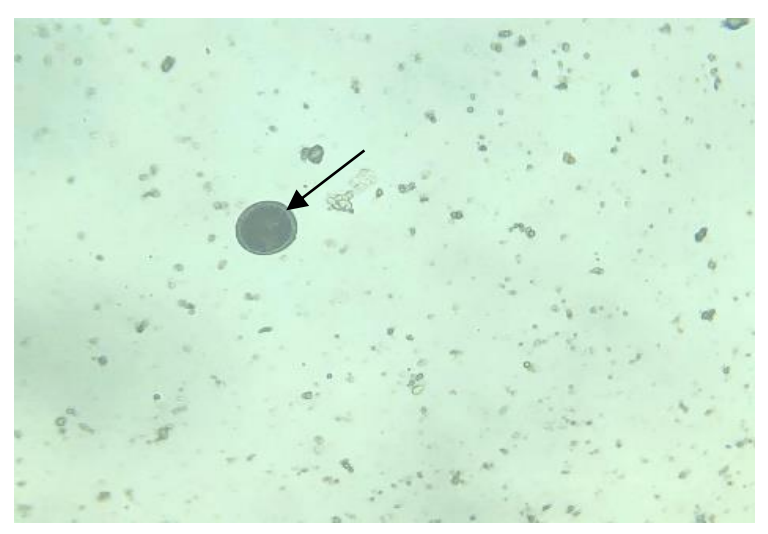

Figure 1. Toxocara cati egg 
After detecting Toxocara cati eggs, positive stool samples were collected from Toxocara cati eggs which were then counted (in the Mc Master counting room) using a microscope with 40 magnification. The number was multiplied by 40 . Approximately 200 eggs were used in each petri dish-storage media.

The graph of the durability of eggs in feces that are positive for Toxocara cati with various in vitro media using $0.9 \% \mathrm{NaCl}, 1 \%$ PBS, and 1\% CMC for 24 hours and 48 hours are as follows:

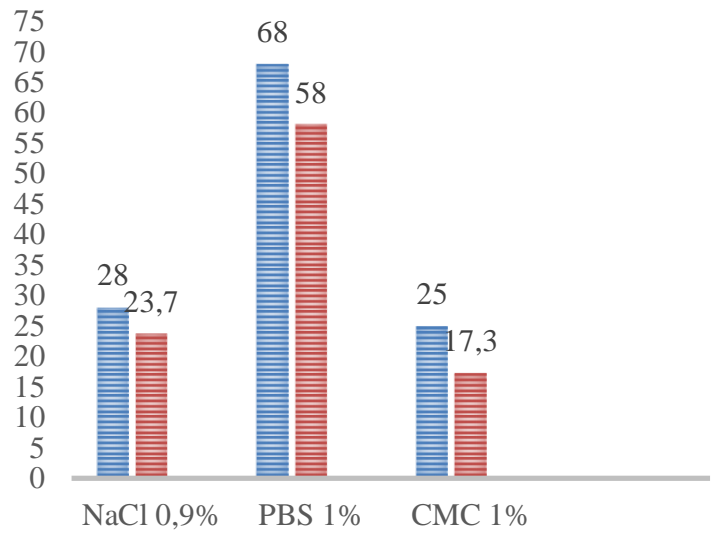

Figure 2. Percentage of Durability of Toxocara cati Eggs on in vitro media for 24 hours (blue) and 48 hours (yellow).

The graph of the survival percentage of Toxocara cati eggs on in vitro media for 24 shows that $\mathrm{NaCl}$ is $28 \%$; PBS $68 \%$; CMC $5 \%$ and at 48 hours examination showed $23.7 \%$ $\mathrm{NaCl}$; PBS 58\%; CMC 17.3\%. Based on these results, the best medium for testing the durability of Toxocara cati worm eggs was 1\% PBS media. The excess of $1 \%$ PBS can store the quality of worm eggs well compared to the others. It is proven in the bar chart in Figure 2.

The results of this study, PBS solution had the best results compared to $\mathrm{NaCl}$ and $\mathrm{CMC}$ at 24-hour and 48-hour observations for the durability of Toxocara cati worm eggs. Research conducted by Ekawasti et al. (2017) that PBS media is the best medium for reproducing eggs, larvae and adult worms of Nematodes. PBS is a physiological solution as a solvent in various living cell biology studies including the correct osmolarity to keep cells in an isotonic state based on saltwater, sodium chloride, sodium phosphate (some formulations), potassium chloride and potassium phosphate. This buffer will help cells maintain a $\mathrm{pH}$ consistency to survive (Beriajaya and Copeman, 2006).

Phosphate Buffer Saline (PBS) contains nutrients that can supply the needs of worm eggs, which are isotonic, able to maintain osmotic and electrolyte balance to survive. Worm eggs have a long shelf life in wet conditions (watering environment) because many of each cell is water. The three media can become storage media because they are liquid (Ekawasti et al., 2017).

According to Detha et al. (2019), in their research explaining that PBS solution was used as a diluent solution in Horse milk before treatment on MRS media, this study stated that PBS solution did not change the structure or $\mathrm{pH}$, which could be detrimental to research results. Kencana et al. (2013) used PBS solution as a mixture of organ scrubbing suspension as a diluent medium. Zagueu et al. (2018) used PBS media to determine the effect of Maytenus senegalensis (Lam.) extract on eggs, larvae, and adult worms of Haemoncus contort in vitro.

\section{CONCLUSION}

Based on the results of this study, 2 (6.67\%) samples of cat feces were positive for Toxocara cati out of a total of 30 samples of cat feces and the best in vitro media in testing the durability of Toxocara cati worm eggs for 24 hours and 48 hours was $1 \%$ PBS media. namely $68 \%$ (24 hours) and 58\% (48 hours).

\section{ACKNOWLEDGEMENT}

Thank you to Lembaga Penelitian dan Pengabdian Masyarakat (LPPM) Universitas Wijaya Kusuma Surabaya which is stated in the Rector's Decree Number 19 of 2021 concerning Recipients of the Research Fund of Universitas Wijaya Kusuma Surabaya in 2021.

\section{REFERENCE}

Beriajaya, S. D., and D. B. Copeman. 2006. Haemonchus contortus and Trichostrogylus colubriformis in pen-trails with Javanese thin tail sheep and Kacang cross Etawah goats. Vet Paras. 135:315323.

Cunningham, A. A., D. Buxton and K. M. Thomson. 1992. An Epidemic of Toxoplasmosis in a Captive Colony of Squirrel Monkeys (Saimiri Sciureus). J. Comp. Pathol. 107:207-219. 
Detha, A., F. U. Datta, E. Beribe, N. Foeh dan N. Ndaong. 2019. Karakteristik Bakteri Asam Laktat yang Diisolasi dari Susu Kuda Sumba. Jurnal Kajian Veteriner. (7)1 : 8592.

Ekawasti, F., Suhardono, D. H. Sawitri, D.A. Dewi, A. H. Wardhana, \& E. Martindah. 2017. Media Penyimpanan Telur, Larva dan Cacing Nematoda sebagai Media Uji In Vitro. Prosiding Seminar Nasional Teknologi Peternakan dan Veteriner 2017.

Eslahi, A.V., M. Badri, A. Khorsidi, H. Majidiani, E. Hooshmand, H. Hosseini,... \& M. Zibaei. 2020. Prevalence of Toxocara and Toxascaris infection among human and animals in Iran with metaanalysis approach. BMC infectious diseases, 20(1), 1-17.

Hildreth, A.M., M Stephen. Vantassel, E Scott. Hygnstrom, 2010. Feral Cats and Their Management. University of Nebraska Lincoln.

Ikrom, D.T.R. Asih, R.A. Wira, B.B. Perkasa, R.N. Tiara, dan Wasito. 2014. Studi In Vitro Ekstrak Etanol Daun Kamboja (Plumeria alba) sebagai Anti Aeromonas hydrophila. Sain Veteriner. ISSN : $0126-$ 0421.

Kencana, G. A. Y., I. G. N. K. Mahardika, I. B. K. Suardana, I. N. M. Astawa, N. M. K. Dewi, dan G. N. N. Putra. 2012. Pelacakan Kasus Flu Burung pada Ayam dengan Reverse Transcriptase Polymerase Chain Reacion. Jurnal Veteriner. 13 (3) : 303308.

Kusnoto. 2005. Prevalensi Toxocariasis pada Kucing Liar di Surabaya Melalui Bedah Saluran Pencernaan. Media Kedokteran Hewan. 21(1): 7-11.

Koesdarto, S., Mahfudz, S. Mumpuni, Kusnoto. 2000. Perbedaan struktur dan morfologi diantara telur cacing toxocara. Journal Universitas Airlangga. 1(2): 1-9.

Luty, L. 2001. Prevalence of Species of Toxocara in dogs, cats and red foxes from the Poznan region, Poland. Journal of Helminthology. 75 : 153-156.

Manurung, J., dan Beriajaya. 2004. Uji in vitro ekstrak daun dan kulit buah nanas (Ananas comosus) terhadap daya tetas telur dan mortalitas cacing Haemanchus contortus. Bogor (Indonesia): Pusat Penelitian dan Pengembangan Peternakan.

Manurung, R. S. 2012. Infeksi Toxocara Sp. pada Hewan Peliharaan di Kelurahan Padang Bulan Tahun 2012. Hasil Penelitian. FK Universitas Sumatera Utara. Medan.

Morsy, T.A. 2020. Toxocariasis: Visceral And Ocular Larva Migrans. Journal of the Egyptian Society of Parasitology. 50 (1) : 40-48.

Nealma, S., I.M. Dwinata, dan I.B.M. Oka. 2013. Prevalensi infeksi cacing Toxocara cati pada kucing lokal di wilayah Denpasar. J. Indo. Med. Vet. 2(4):428-436.

Ursche, A. L., A. Gyorke, V. Mircean. M.O. Dumitrache, A. R. Codea, V. Cozma. 2021. Toxocara cati and Other Parasitic Enteropathogens: More Commonly Found in Owned Cats with Gastrointestinal Signs Than in Clinically Healthy Ones. Pathogens (10): 198.

Roeswandono, O. R. P. A. Mussa, M. J. A. Pangaribuan, B. U. Palgunadi. 2019. Perhitungan telur Toxocara Cati Dan Jumlah Sel Darah Putih Pada Kucing Liar (Felis Catus) Di Dukuh Kupang Surabaya. Jurnal Vitek Bidang Kedokteran Hewan. 9.: $18-23$

Sudardjat S. 2012. Epizootiologi Parasit Cacing dan Kausa Bakteri. Jakarta: Gita Pustaka.

Zangueu, C. B., A. P. Olounlade, M. Ossokomack, Y. N. N. Djouatsa, G. G. Alowanou, A. G. B. Azebaze,... \& M. S. Hounzangbe-Adote. 2018. In vitro effects of aqueous extract from Maytenus senegalensis (Lam.) Exell stem bark on egg hatching, larval migration and adult worms of Haemonchus contortus. BMC veterinary research, 14(1), 1-11. 